\title{
DESIGNING A GREEN MARKETING BEHAVIORAL PATTERN FOCUSING ON POULTRY PRODUCTS
}

\author{
TALEBI, P. - OMIDI-NAJAFABADI, M.* - LASHGARARA, F. \\ Department of Agricultural Extension and Education, Science and Research Branch, Islamic \\ Azad University, Tehran, Iran \\ *Corresponding author \\ e-mail:m.omidi@srbiau.ac.ir \\ (Received $17^{\text {th }}$ Jun 2018; accepted $22^{\text {nd }}$ Aug 2018)
}

\begin{abstract}
Green marketing has rapidly emerged as a global phenomenon around the world .As a result, some companies have responded to environmental challenges by applying green marketing strategies. However, with the increasing importance of environmental and health issues and the concept of social responsibility among consumers, recognizing behavior by actors and companies related to green products marketing is necessary. Therefore, this study helps to improve the understanding of green marketing behavior, which plays an important role in improving community health and economic growth. This study aims to design a green marketing behavioral pattern focusing on poultry products. The statistical population of this study is 145 actors who are involved in the production, distribution, promotion and pricing of green poultry products in Iran (Gilan Province). The findings indicate that attitudes toward green marketing ( $\beta$ : 0/94), subjective norms in relation to green marketing ( $\beta: 0 / 90)$ and feasibility ( $\beta$ : $0 / 67$ ) had significant positive influences on intention toward green marketing. In addition, the results of green marketing behavior revealed that intention toward green marketing ( $\beta: 0 / 48)$, feasibility $(\beta: 0.28)$ and government support $(\beta=0.56)$ were the three variables that influenced green marketing behavior, with government support having the greatest impact.
\end{abstract}

Keywords: attitudes, subjective norms, feasibility, self-efficacy, decomposed theory of planned behavior, planned behavior theory, green products

\section{Introduction}

In conventional marketing, the needs of customers are identified and satisfied (Kotler, 2003) in the most profitable manner (CIM, 2011) without accounting for social welfare and environmental issues .In other words, conventional marketing focuses on the economic desires of the company and the direct benefits of the products (Khan and Rafat, 2015). In Iran, conventional marketing methods for agricultural production are associated with high costs and are incompatible with sustainable development goals. Among the major problems that Iranian traditional marketing faces in relation to agricultural products are price instability, the high cost and inadequacy of transportation, lack of producer knowledge of market situations due to the inadequacy of the market information system, lack of facilities such as warehouses, high cost of production and waste during the various stages of production, the existence of brokers and the inadequacy of government support in market development and marketing policies. In addition to the lack of green marketing options, information and targeted advertising, the lack of public interest in environmental programs is another challenge in Iran (based on interviews with experts from the Jahad Agricultural Organization).

Since traditional marketing techniques no longer address all of the issues of modern markets, the implementation of green marketing is expected to improve marketing strategies not only by providing long-term financial performance for companies, but also by improving their environmental performance (Kotler et al., 2010; Luchs et al., 
2010; Liu et al., 2012; Malhotra et al., 2012). Thus, green marketing incorporates a wide range of activities, including product modifications, changes to the production process and, packaging changes, and also modifies the advertising approach (AMA, 2015; Polonsky, 2007). Additionally, Pride and Ferrell (1993) and Grove et al. (1996) noted that the term "green marketing" refers to an organization's efforts to design, promote, price and distribute goods that will not cause damage to the environment. Polonsky (1994) identified several reasons for companies to adopt alternative marketing: (1) social responsibility, i.e., a company understands that it is a members of a wider community and therefore should behave in an environmentally friendly manner and achieve both environmental and profit-related objectives; (2) opportunity, i.e., as people become increasingly concerned about the environment, the benefits of adopting alternative marketing strategies increase, and companies that have incorporated green marketing into their corporate strategy may enjoy a sustainable competitive advantage over companies that have not; and (3) governmental pressure, i.e., governments are attempting to establish regulations that control the amount of dangerous waste produced by companies and are issuing environmental licenses to control those wastes.

Ottman (2011) believes that the companies' product marketing function may be useful for two reasons. First, when a company adopts a program of environmentally friendly products, its distribution, pricing and promotion of the company image and reputation among customers can improve. Second, implementation of a green marketing plan may increase sales by giving a company access to new market segments.

In organic poultry production, the number of birds, nutritional factors, lighting, environmental conditions and even labor force prices and packaging are involved in the quality of the product. In general, the entire production cycle from corn and millet to the final ring of the slaughterhouse should be conducted without chemical interference. Due to the complexity of the production process, organic poultry production in Iran requires a suitable foundation that may take several years to establish. However, the first step in organic poultry in Iran is producing poultry without the use of antibiotics, meaning that during the breeding period, no antibiotic agent is injected into or consumed by poultry that are labeled as green. The northern provinces of Iran, due to their geographical location and the availability of appropriate physical resources, are potentially suitable for the poultry industry (Suri, 2014). Therefore, Gilan province was selected as a northern province in Iran with a high safety factor in the production of green poultry. Research in this field indicates that producers and actors in Gilan province have undergone a positive trend toward green marketing and organic farming because of the competitive and health advantages of such products. However, in recent years, early efforts at green marketing in Iran have focused only on the production; due to the lack of information, no serious efforts have yet been made in the areas of packaging, distribution and pricing. In addition, because of the high cost of organic production and the lack of specialized staff and government policies, this tendency has not led to the associated behavior. Therefore, this study aimed to examine green marketing behavior (GMB) predictors by designing a behavioral pattern.

According to market researcher Mintel, approximately $12 \%$ of the U.S. population can be identified as true greens, that is, consumers who seek out and regularly buy socalled green products. Another $68 \%$ can be classified as light greens, consumers who sometimes buy green products (Hanas, 2007). Research has also shown that the market grew by approximately 41\% from 2004 to 2009 (Mintel, 2010). According to a new survey, most Europeans would be prepared to change their purchasing habits and buy 
more environmentally friendly products, but many feel that they lack information and distrust manufacturers' environmental claims (European Commission, 2013).

A change in agricultural practices is equivalent to changing the culture and mindset of farmers, which can be achieved only by prolonged interaction. Nongovernmental organizations (NGOs) have demonstrated capabilities to this effect (Shenoy, 2003). In Iran, due to the dispersion of active actors in the field of green production and green marketing as well as the lack of government support, official and accurate statistics regarding those who are engaged in green marketing are not available. With the emergence of the phenomena of social responsibility and green marketing, the private sector and NGOs play an important role in promoting and advertising organic farming activities; however, there is still little consumer participation in these activities (Sabori, 2009).

Academic studies on green marketing began in the 1990s and focused on concepts and approaches (Polonsky, 1994; Peattie, 2001; Peattie and Crane, 2005; Rex and Baumann, 2007), the evaluation of green marketing strategies (Polonsky and Rosenberger, 2001; Rivera Camino, 2007), the relationship between green marketing and consumers (Laroche et al., 2001; Ginsberg and Bloom, 2004; D’Souza et al., 2006; Lee, 2008) and the application of green marketing (Johri and Sahasakmontri, 1998; Teisl et al., 2002; Gurau and Ranchhod, 2005). Other researchers reported that there is a significant relationship between green product features, promotion, pricing and distribution and consumers' green behavior (Shahlaee Bagheri, 2014; Boztepe, 2012). Therefore, higher levels of green consciousness lead to greater influence by the mediating factors of attitude, subjective norm, and behavioral control on behavioral intention and the consequent actual behavior. Many studies applied the theory of planned behavior (TPB) to explore consumers' attitude, intention and actual buying behavior with regard to green products (Arvola et al., 2008; Smith and Paladino, 2010; Tanner and Wölfing Kast, 2003; Tarkiainen and Sundqvist, 2005).

The theoretical model of GMB is a set of factors. To better understand these factors, the most important are described in Table 1.

Table 1. Constructing the research model factors

\begin{tabular}{|c|c|c|}
\hline Factors & & Definition \\
\hline Attitude & $\mathrm{H} 1$ & $\begin{array}{l}\text { The degree to which the individual favors the behavior being examined (Ajzen, } \\
\text { 1991) }\end{array}$ \\
\hline Perceived risk & $\mathrm{H} 2$ & $\begin{array}{l}\text { An actor's perceptions of the uncertainty and adverse consequences of engaging } \\
\text { in an activity (Bauer, 1960; Taylor, 1974) }\end{array}$ \\
\hline $\begin{array}{l}\text { Perceived } \\
\text { usefulness }\end{array}$ & $\mathrm{H} 3$ & $\begin{array}{l}\text { The degree to which the individual believes that a technology would improve his } \\
\text { or her job performance (Davis, 1989) }\end{array}$ \\
\hline Ease of use & $\mathrm{H} 4$ & $\begin{array}{l}\text { The degree to which an innovation is easy to understand and operate (Rogers, } \\
\text { 2003) }\end{array}$ \\
\hline $\begin{array}{l}\text { Subjective } \\
\text { norms }\end{array}$ & H5 & $\begin{array}{l}\text { An individual's perception of social normative pressures, or relevant others' } \\
\text { beliefs that he or she should or should not perform a behavior (Ajzen, 1991). } \\
\text { Subjective norms are decomposed into injunctive norms and descriptive norms }\end{array}$ \\
\hline $\begin{array}{l}\text { Injunctive } \\
\text { norms }\end{array}$ & H6 & $\begin{array}{l}\text { People's beliefs about what ought to be done (Cialdini et al., 1990; Lapinski and } \\
\text { Rimal, 2005) }\end{array}$ \\
\hline $\begin{array}{l}\text { Descriptive } \\
\text { norms }\end{array}$ & $\mathrm{H} 7$ & $\begin{array}{c}\text { Beliefs about what is actually done by most others in one's social group (Cialdini } \\
\text { et al., 1990; Lapinski and Rimal, 2005) }\end{array}$ \\
\hline
\end{tabular}




\begin{tabular}{c|c|c}
\hline $\begin{array}{c}\text { Feasibility } \\
\text { (PBC) }\end{array}$ & H8 & $\begin{array}{c}\text { Beliefs regarding access to the resources and opportunities needed to perform a } \\
\text { behavior or, alternatively, the internal and external factors that may impede the } \\
\text { performance of the behavior (Ajzen, 1985, 1991; Ajzen and Driver, 1992; Ajzen } \\
\text { and Madden, 1986; Madden et al., 1992) }\end{array}$ \\
\hline Self-efficacy & H9 & $\begin{array}{r}\text { An individual's self-confidence in his/her ability to perform a behavior (Bandura, } \\
\text { 1977) }\end{array}$ \\
\hline $\begin{array}{c}\text { Facilitating } \\
\text { conditions }\end{array}$ & H10 & $\begin{array}{r}\text { The availability of resources needed to engage in a behavior, such as time, } \\
\text { money or other specialized resources (Taylor and Todd, 1995). In other words, } \\
\text { the person believes that this behavior is in his or her control }\end{array}$ \\
\hline GMI & H11 & $\begin{array}{r}\text { An indication of an individual's readiness to perform a given behavior. It is } \\
\text { assumed to be an immediate antecedent of behavior (Ajzen, 2002) }\end{array}$ \\
\hline GMB & H12 & $\begin{array}{r}\text { The actors offer an environmentally friendly product that is not deleterious to } \\
\text { health, the environment and society (based on qualitative research). Therefore, } \\
\text { the term "behavior" is calculated with a mixture of green marketing aspects, } \\
\text { including green product, green price, green promotion and green location }\end{array}$ \\
\hline
\end{tabular}

Surprisingly, there are few studies on Iranian agriculture in general, and none specific to green marketing that provides a behavioral pattern. For this study, a green marketing behavioral pattern was designed for actors in green poultry production in Gilan province. The author of this article had the following aims:

1. Describe certain personal and professional characteristics of actors in green poultry production.

2. Determine the effects of attitude, subjective norms, feasibility (perceived behavioral control), governmental support, and knowledge and intention toward green marketing (GMI) in green poultry production on GMB.

3. Provide a path analysis model of the green marketing behavioral pattern of actors in green poultry production.

\section{Materials and methods}

This is an applied study based on quantitative research, and the method of analysis used is correlation. This study focused on Gilan province, which has the potential capacity to serve as a poultry production zone in northern Iran .Due to the lack of sufficient facilities, most Iranian poultry farms are not used to produce green poultry. The production and marketing of this product are controlled by private companies that are responsible simultaneously for production, monitoring and marketing; therefore, accurate statistics regarding the amount of green poultry production and those engaged in it in Gilan were not available. However, information was informally obtained from experts. The sample in this study is 145 people who are involved in the production, distribution, promotion and pricing of green poultry in Gilan province; they are referred to as the actors $(n=145)$. The study was conducted as a census study because of the small size of the population of experts, and 128 usable questionnaires were obtained from interviews with the actors.

The main instrument used for data collection was a questionnaire, which was developed from a review of the related literature, in 8 sections (present status of GMB, intention toward green marketing (GMI), attitude toward green marketing, review of the actor's subjective norms, green marketing feasibility, review of government support, assessment of the actor's knowledge and description of the actor's personal and 
professional characteristics). The evaluations were based on two 5-point Likert scales ranging from 1 (strongly disagree) to 5 (strongly agree).

The content and validity of the questionnaire were established and revised with the help of experts, including faculty members and a few specialists in green marketing. A pretest study was conducted with 20 experts randomly chosen from these populations; the reliability of the questionnaire was verified (calculated Cronbach's alpha was 87.3 and ordinal theta coefficients were $81-94 \%$ ), confirming the suitability of the items.

This study contained two types of variable: 1) GMB (Y2) as the final dependent variable, which was measured by the respondents' answers to 19 items, and 2) GMI as an intermediate dependent variable, which was measured by 5 items on the Likert scale. Independent variables included governmental support, actors' knowledge of green marketing, actors' attitude, actors' subjective norms and feasibility of green marketing.

The hypotheses were measured by studying the relationships between the variables and their direct and indirect effects. Structural equation modeling (SEM) is a general approach to data analysis that can accommodate either observable or latent variables (or factors) within structural models. This study used descriptive statistics and SEM. Following data mining, descriptive statistics and SEM analysis were conducted with SPSS20 and AMOS20 software, respectively.

Although some authors support the TPB model, whether it can predict all the determinants of human behavior has been questioned (Ajzen, 1991). Therefore, many researchers have proposed revised models to predict behavior accurately (Bond et al., 2009; He, 2012; Läpple and Kelley, 2010; McCarthy, 2007; Wauters and Mathijs, 2010). Many studies have applied the TPB to explore attitude, intention and actual behavior with regard to green products (Arvola et al., 2008; Smith and Paladino, 2010; Tanner and Wölfing Kast, 2003; Tarkiainen and Sundqvist, 2005). Additionally, influential studies have focused on green purchasing and green consumers, but none have provided an exhaustive study integrating all the effective elements from several viewpoints in the form of an individual study. In this study, the theoretical basis of the model is the planned behavior theory by Icek Ajzen and the decomposed theory of planned behavior described by Taylor and Todd. To better predict the green marketing behavioral pattern of actors in green poultry production and to evaluate the model performance, related variables used by other authors were also used to develop this model (Fig. 1).

\section{Results}

\section{Personal characteristics}

The results showed that of the 128 respondents, 4 (3.1\%) were female and 124 (96.9\%) were male; the average age and average work experience of the respondents were 40 and 9 years, respectively. Of the actors, $35.2 \%$ had an associate's degree. The actors' knowledge of green marketing was measured by a test (correct or wrong answers); the results indicated that their average level of green marketing knowledge was $65 \%$.

\section{Significance test}

SEM was used to verify the research model. As shown in Table 2, some paths are significant and others are not significant. 


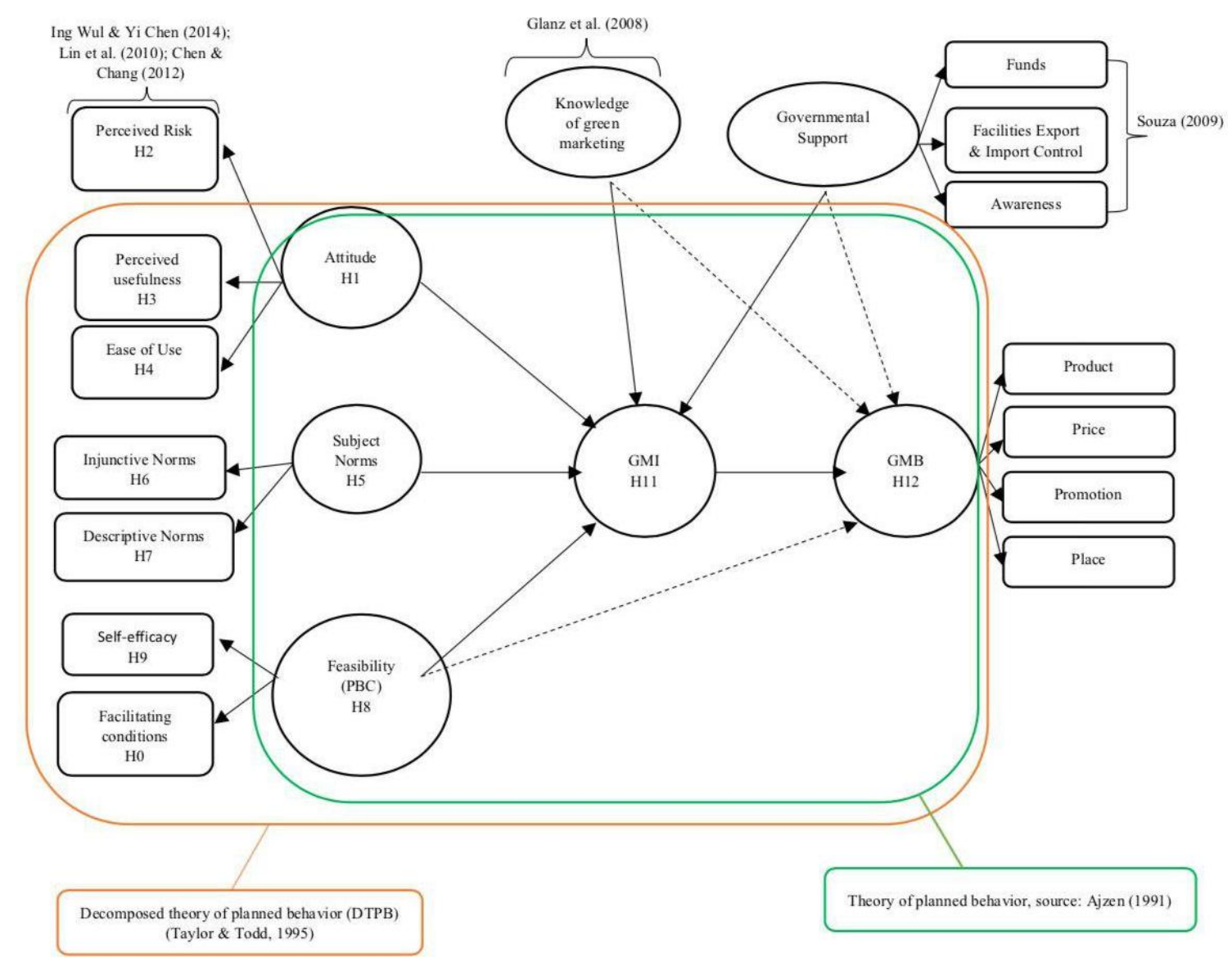

Figure 1. Theoretical model

Table 2. Regression weight and significance test of paths

\begin{tabular}{c|c|c|c|c}
\hline Path & Estimate & S.E. & C.R. & P value \\
\hline Attitude $\longrightarrow$ intention & 0.939 & 0.053 & 17.679 & $* * *$ \\
\hline Subjective norms $\rightarrow$ intention & 0.899 & 0.077 & 11.700 & $* * *$ \\
\hline Feasibility $\longrightarrow$ intention & 0.657 & 0.070 & 9.354 & $* * *$ \\
\hline Feasibility $\longrightarrow$ behavior & 0.161 & 0.062 & 2.594 & $0 / 009 * *$ \\
\hline Governmental support $\longrightarrow$ intention & 0.146 & 0.194 & 0.752 & $0 / 452$ n.s. \\
\hline Governmental support $\longrightarrow$ behavior & 0.619 & 0.122 & 5.060 & $* * *$ \\
\hline Knowledge $\longrightarrow$ intention & -0.009 & 0.042 & -0.207 & $0 / 836$ n.s. \\
\hline Knowledge $\longrightarrow$ behavior & -0.044 & 0.045 & -0.967 & $0 / 334$ n.s. \\
\hline Intention $\longrightarrow$ behavior & 0.422 & 0.097 & 4.342 & $* * *$ \\
\hline Knowledge $\longrightarrow$ self-efficacy & 0.051 & 0.018 & 2.780 & $0.005 * *$ \\
\hline
\end{tabular}

$* \mathrm{P}<0.05, * * \mathrm{P}<0.01, * * * \mathrm{P}<0.001$

As shown in Table 3, the variable attitude at 0.94 has the greatest effect on GMI, and the variable governmental support at 0.56 has the greatest effect on the dependent variable $(\mathrm{GMB})$. 
Table 3. Standardized regression weights of significant paths

\begin{tabular}{c|c}
\hline Path & Estimate \\
\hline Attitude of actors $\longrightarrow$ GMI & 0.94 \\
\hline Subjective norms of actors $\longrightarrow$ GMI & 0.90 \\
\hline Feasibility $\longrightarrow$ GMI & 0.67 \\
\hline Feasibility $\longrightarrow$ GMB & 0.28 \\
\hline Governmental support $\longrightarrow$ GMB & 0.56 \\
\hline GMI $\longrightarrow$ GMB & 0.48 \\
\hline Knowledge of actors $\longrightarrow$ self-efficacy & 0.12
\end{tabular}

\section{Structural analysis and measures of fit}

Model evaluation is one of the most unsettled and difficult issues of structural modeling. SEM was used to verify the research model with a covariance relationship among antecedents. The following goodness-of-fit measures were used to confirm the appropriateness of the research model for this study: $P=0.213, \mathrm{CMIN} / \mathrm{DF}=1.431$, $\mathrm{GFI}=0.830, \mathrm{AGFI}=0.820, \mathrm{CFI}=0.980$ and $\mathrm{RMSEA}=0.037$. These indices suggest a good model approximation to the sample data, and regression models are shown below:

1. $\mathrm{GMB}=0.28 \times$ feasibility $+0.48 \times \mathrm{GMI}+0.56 \times$ governmental support

2. $\mathrm{GMI}=0.94 \times$ attitude $+0.9 \times$ subjective norms $+0.67 \times$ feasibility

Figure 2 shows latent variables that influence GMB and GMI. The effect of knowledge of green marketing and government support on intention is not significant. The final model of the green marketing behavioral pattern of actors in green poultry production in Gilan province is shown in Figure 3.

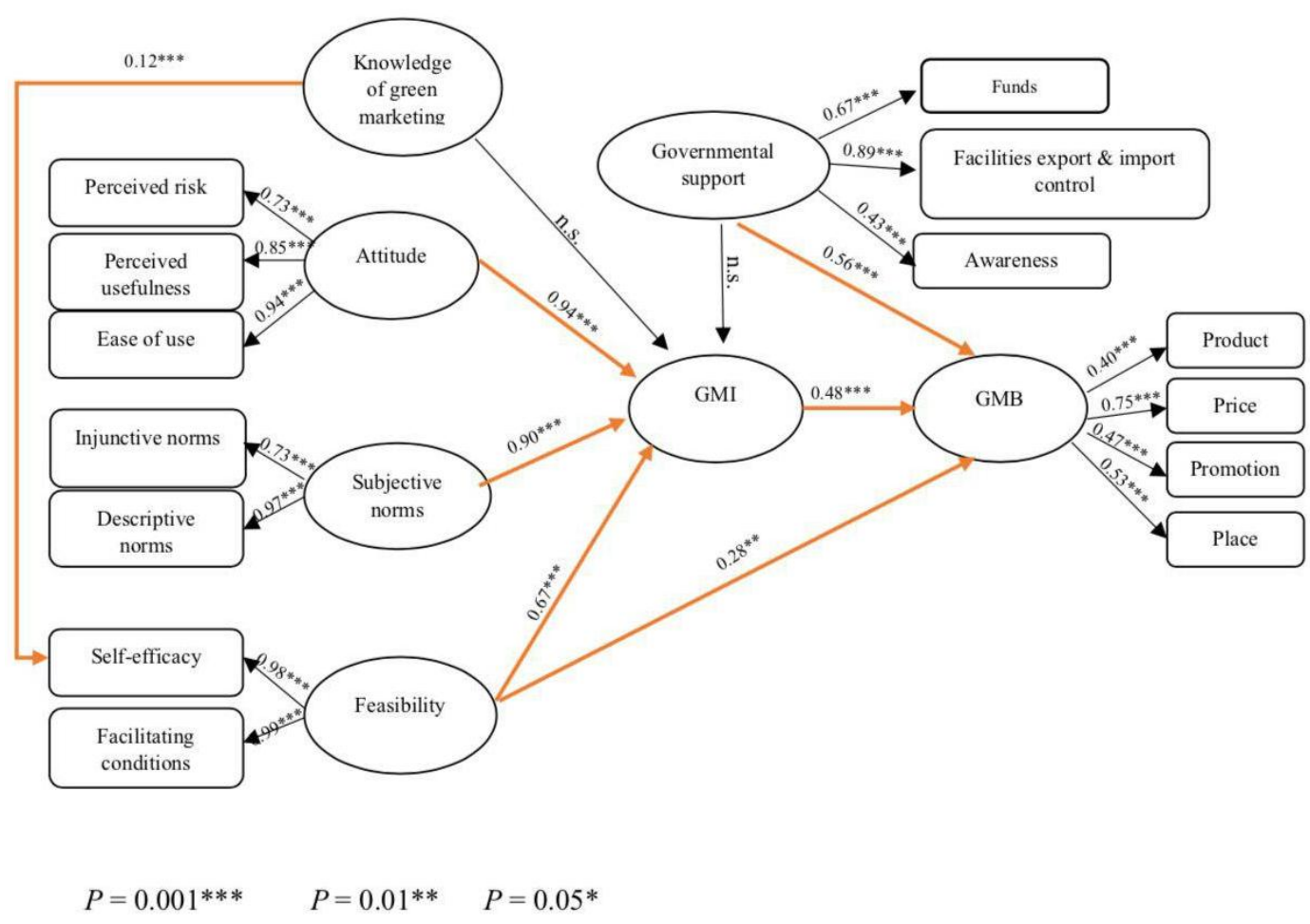


Figure 2. Model of latent variables

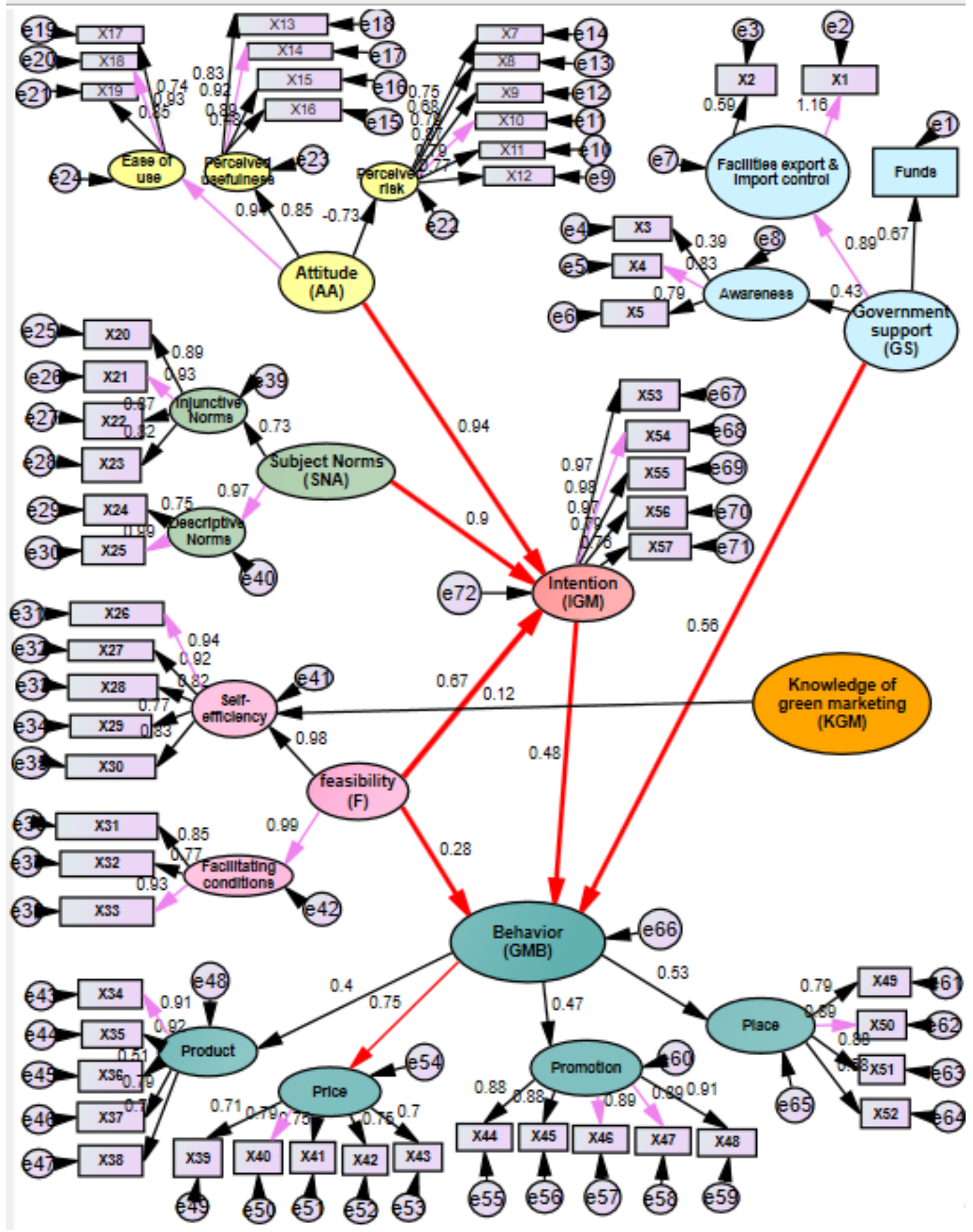

Figure 3. Structural equation model for estimated standard coefficients

\section{Discussion}

The purpose of this study was to design a green marketing behavioral pattern focusing on poultry products. It was predicted that certain elements would affect GMB. The results show how the TPB can increase our understanding of the factors that influence and determine GMB. In this regard, political (government support) and 
educational (knowledge of green marketing) elements were also used to better predict the results of this model.

According to the analysis of the results, it can be deduced that:

- The attitude of the actors has a significant positive effect on their GMI. Our finding is consistent with the findings of Ing Wul and Yi Chen (2014), Knabe (2012), Lin et al. (2010), Arvola et al. (2008), Smith and Paladino (2010), Tarkiainen and Sundqvist (2005) and Asadollahpour et al. (2016).

- The subjective norms of the actors have a significant positive effect on their GMI. This finding is in accordance with the findings of Ing Wul and Yi Chen (2014), Knabe (2012), Lin et al. (2010), Arvola et al. (2008), Smith and Paladino (2010), Tarkiainen and Sundqvist (2005), Soonthensmai (2001) and Asadollahpour et al. (2016).

- Feasibility has a significant positive effect on the actors' GMI. This finding supports the findings of Ing Wul and Yi Chen (2014), Knabe (2012) and Asadollahpour et al. (2016).

- Feasibility has a significant positive effect on the actors' GMB. This finding supports the findings of Ing Wul and Yi Chen (2014) and Asadollahpour et al. (2016).

- Governmental support has a significant effect on the actors' GMB. This finding is consistent with the findings of Chen and Chai (2010), Mei et al. (2012), Diekmeyer (2008) and Punitha and Rahman (2011).

- GMI has a significant positive effect on the actors' GMB. This finding is in accordance with the findings of Ing Wul and Yi Chen (2014), Knabe (2012), Lin et al. (2010), Arvola et al. (2008), Smith and Paladino (2010), Tarkiainen and Sundqvist (2005), Asadollahpour et al. (2016), Soonthensmai (2001) and Che Hsu et al. (2016).

- The knowledge of the actors has a positive effect on their self-efficacy.

- The effect of the actors' knowledge on their GMI is not significant. This finding confirms the results of Maichum et al. (2016).

The results indicated that first, the three components of intention, actors' attitude (0.94), actors' subjective norms (0.90), and feasibility (0.67), had significant positive effects on GMI. Additionally, the three variables GMI (0.48), governmental support (0.56) and feasibility (0.28) each contributed to the prediction of perceptions of GMB and were found to have significant positive effects on GMB. Attitude (0.94) had the most significant influence on GMI and thus was the strongest predictor of GMI, followed by subjective norms (0.90) and feasibility (0.67). Additionally, governmental support (0.56) had the greatest effect on GMB. The overall results confirmed that the TPB model and its measures were suitable for the studied group.

The reason that knowledge of green marketing was not a strong predictor of GMB and GMI in this study may be that most of the actors had no education in green marketing. The results indicated that knowledge of green marketing had a small effect on self-efficacy (0.12) and an indirect effect on feasibility. These findings are consistent with those of Ing Wul and Yi Chen (2014), Asadollahpour et al. (2016), Chen and Deng (2016) and Maichum et al. (2016). 


\section{Conclusion}

Although levels of analysis are not necessarily mutually exclusive, there are three general levels into which social science research may fall: microlevel; mesolevel, or middle range; and macrolevel (Blalock, 1970). Based on the results of this study, the following recommendations are presented at these three levels:

Macrolevel: The macrolevel is the national policy governing these activities in the country, including legislation and regulations. The analysis focuses on how these national policies influence activities in an institution or organization or at the field level. International influences on laws and policies may also be examined (ITCILO, 2009).

Among the variables constructing the GMB factor, governmental support was identified as the most important. In Iran, due to the lack of specific government policies related to organic products, there is little potential for organic poultry production; thus, government agencies and policy makers should consider specific policies such as:

- Allocating funds to develop organic production infrastructures

- Preparations and government support to attract foreign investors

- Allocating targeted funds to the construction of modern slaughterhouses in accordance with European standards

- Increasing government support to increase the ability of actors to produce organic products

Mesolevel: At the mesolevel, the focus is on how institutions such as NGOs and development organizations operate in terms of service provision and implementation and how they influence national policy. At this level, the focus is on education services, the role of the public and private sectors, the level of decentralization and the level of expertise in the institutions (ITCILO, 2009).

The importance of the variable subjective norms among the variables that construct the GMB factor has been explained by Montaño and Kasprzyk (2008). Montaño and Kasprzyk (2008) believe that if a person realizes that the result is a positive behavior, he or she will have a positive attitude toward performing that behavior; in addition, if others are positive about the behavior and the individual is motivated to satisfy others' expectations, a positive subjective norm is expected. Studies have shown that individuals' subjective norms affect GMI, and the results of this study confirmed the positive relationship between these two variables. As a result, it is recommended that institutions and service organizations use modern methods of information and advertisement, such as social media and the Internet, to develop green marketing campaigns to create positive subjective norms.

Microlevel: At the microlevel, the focus is on female and male consumers. The analysis should focus on how to identify the contexts-related specific needs and priorities of consumers and examine the extent to which gender roles, relationships and cultural issues are key (ITCILO, 2009).

Among the variables that construct the GMI factor, attitude was identified as the most important. Montaño and Kasprzyk (2008, p. 71) believe that "Attitude is determined by the individual's beliefs about outcomes or attributes of performing the behavior weighted by evaluations of those outcomes or attributes." In Iran, green marketing is related mostly to production, and no serious action has been taken for green packaging, distribution and pricing. Due to high production costs and the risk of customer distrust of green products, there is the possibility of financial losses for the 
actors. As a result, there is no positive attitude toward green marketing, and the impact of this variable on GMI is known to be the most important. Therefore, justifying the profitability of green products due to increased consumption of these products in the coming years and managing production, pricing, promotion and distribution plans in the framework of export standards may be fruitful for companies.

In sum, the results of this study showed that positive attitudes, appropriate subjective norms, and the feasibility of green marketing improve actors' GMI, and this positive intention will have an impact on GMB for organic production. In addition, government policies and support for the development of organic agriculture will significantly influence the process of GMB. Therefore, with a view to highlighting the financial and commercial aspects of organic agriculture, the agricultural extension as an educational institution can play an important role in this field with facilities and activities for educational and cultural promotion and the implementation of incentive policies.

The novelty of this study is its consideration of political, social, cultural, economic and educational dimensions in the hope that the results will be useful to managers, researchers, practitioners, and policy makers and contribute to future research as a reference. Also in this study, the theoretical basis of the model is combination of the planned behavior theory by Icek Ajzen and the decomposed theory of planned behavior described by Taylor and Todd, on the other hand to better predict the green marketing behavioral pattern of actors in green poultry production and to evaluate the model performance, related variables (governmental support, knowledge of green marketing and perceive risk) were also used to develop this model based on interviews with actors and the researchers' view.

There are some recommendations for future studies in this area. First, other aspects of the marketing mix that are considered substitutes for the $4 \mathrm{Ps}$, such as the $4 \mathrm{Cs}$ (consumer, cost, communication, and convenience), and are more customer-oriented should be studied. Additionally, the limitations of the present study include the small size; therefore, future research should include a more comprehensive sample. In this study, based on some interviews and literature review, a questionnaire was developed. For further studies, using Delphi technique and grounded theory, will be suggested.

Acknowledgements. Thanks are expressed to Gilan Veterinary Organization and Jahad Agricultural Organization for their constructive comments.

\section{REFERENCES}

[1] Ajzen, I. (1985): From Intentions to Actions: A Theory of Planned Behavior. - In: Kuhl, J., Beckmann, J. (eds.) Action-Control: From Cognition to Behavior. Springer, Heidelberg, pp. 11-39.

[2] Ajzen, I. (1991): The theory of planned behavior. - Organizational Behavior and Human Decision Processes 50: 179-211.

[3] Ajzen, I. (2002): Perceived behavioral control, self-efficacy, locus of control, and the theory of planned behavior. - Journal of Applied Social Psychology 32(4): 665-683. http://dx.doi.org/10.1111/j.1559-1816.2002.tb00236.

[4] Ajzen, I., Driver, B. L. (1992): Application of the theory of planned behavior to leisure choice. - Journal of Leisure Research 24: 207-224. 
[5] Ajzen, I., Madden, T. J. (1986): Prediction of goal-directed behavior: Attitudes, intentions, and perceived behavioral control. - Journal of Experimental Social Psychology 22: 453-474.

[6] AMA (2015): https://www.ama.org/resources/Pages/Dictionary.aspx?dLetter=G. American Marketing Association, Chicago, IL.

[7] Arvola, A., Vassallo, M., Dean, M., Lampila, P., Saba, A., Lhteenmki, L. et al. (2008): Predicting intentions to purchase organic food: The role of affective and moral attitudes in the theory of planned behaviour. - Appetite 50: 443-454.

[8] Asadollahpour, A., Omidi Najaf Abadi, M., Hosseini, S. J. (2016): Modeling behavior pattern of Iranian organic paddy farmers. - Paddy Water Environ. 14: 221-229.

[9] Bandura, A. (1977): Self-efficacy: Toward a unifying theory of behavioral change. Psychological Review 84(2): 191-215.

[10] Bauer, R. A. (1960): Consumer Behavior as Risk Taking. - In: Hancock, R. S. (ed.) Dynamix Marketing for a Changing World, American Marketing Association, Chicago, IL, pp. 389-98.

[11] Blalock, H. M. (1979): Social Statistics. - McGraw-Hill, New York.

[12] Bond, J. L., Kriesemer, S. K., Emborg, J. E., and Chadha, M. L. (2009): Understanding farmers' pesticide use in Jharkhand India. - Extension Farming Systems Journal 5(1): 5361.

[13] Boztepe, A. (2012): Green marketing and its impact on consumer buying behavior. European Journal of Economic and Political Studies 5(1): 5-21.

[14] Camino, J. R. (2007): Re-evaluating green marketing strategy: A stakeholder perspective. - European Journal of Marketing 41(11/12): 1328-1358.

[15] Chartered Institute of Marketing (2011): http://www.cim.co.uk/. - CIM, UK.

[16] Che Hsu, W., I Huang, K., Ming Hsu, S., Hsuan Huang, C. (2016): A study of behavioral model on green consumption. - Journal of Economics, Business and Management 4(5). DOI: 10.18178/joebm.2016.4.5.420.

[17] Chen, K., Deng, T. (2016): Research on the green purchase intentions from the perspective of product knowledge. - Sustainability 8: 943.

[18] Chen, T. B., Chai, L. T. (2010): Attitude towards the environment and green products: consumers' perspective. - Management Science and Engineering 4: 2739.

[19] Chen, Y.-Sh., Chang, Ch. H. (2012): Enhance green purchase intentions: The roles of green perceived value, green perceived risk, and green trust. - Management Decision 50(3): 502-520.

[20] Cialdini, R. B., Reno, R. R., Kallgren, C. A. (1990): A focus theory of normative conduct: Recycling the concept of norms to reduce littering in public places. - Journal of Personality and Social Psychology 58: 1015-1026.

[21] Davis, F. D. (1989): Perceived usefulness, perceived ease of use, and user acceptance of information technology. - MIS Quarterly 13(3): 319-340.

[22] Diekmeyer, P. (2008): Bribery in Public Procurement: Protecting Your Company from Corruption. - OECD, Paris.

[23] D’Souza, C., Taghian, M., Lamb, P. (2006): An empirical study on the influence of environmental labels on consumers. - Corporate Communication: An International Journal 11(2): 162-173.

[24] European Commission. (2013): 80\% of Europeans are concerned about the environmental impact of products. - http://europa.eu/rapid/press-release_IP-13-653_en.htm.

[25] Ginsberg, J. M., Bloom, P. N. (2004): Choosing the right green marketing strategy. MIT Sloan Management Review 46(1):79-84.

[26] Glanz, K., Rimer, B. K., Viswanath, K. (2008): Health Behavior and Health Education: Theory, Research, and Practice (4th ed.). - Jossey-Bass, San Francisco.

[27] Grove, S. J., Fisk, R. P., Pickett, G. M., Kangun, N. (1996): Going green in the service sector social responsibility issues, implications and implementation. - European Journal of Marketing 30(5): 56-66. 
[28] Gurau, C., Ranchhod, A. (2005): International green marketing: a comparative study of British and Romanian firms. - International Marketing Review 22(5): 547-561.

[29] Hanas, J. (2007): Environmental awareness has not only tipped in the media - it's hit corporate boardrooms as well. Advertising age. - http://adage.com/article/special-reportecomarketing/a-world-green/117113/.

[30] He, C. (2012): Assessment of the impact of organic school meals to improve the school food environment and children's awareness of healthy eating habits. - Department of Planning Faculty of Engineering and Science Aalborg University, PhD Dissertation.

[31] Ing Wul, S., Yi Chen, J. (2014): A model of green consumption behavior constructed by the theory of planned behavior. - International Journal of Marketing Studies 6(5): 119132. DOI: $10.5539 / \mathrm{ijms} . v 6 n 5 p 119$.

[32] International Training Centre of the International Labour Organisation (2009): Introduction to Gender Analysis and Gender-Sensitive Indicators. - Gender Campus. www.focusintl.com/GD124a-\%20Gender\%20Campus\%20-\%20Tools.pdf.

[33] Johri, L. M., Sahasakmontri, K. (1998): Green marketing of cosmetics and toiletries in Thailand. - Journal of Consumer Marketing 15: 265-281.

[34] Khan, M. S., Rafat, A. (2015): Conventional marketing v/s green marketing: myth and reality. - International Journal of Pure and Applied Researches 1(1): 97-104.

[35] Knabe, A. (2012): Applying Ajzen's Theory of Planned Behavior to a Study of Online Course Adoption in Public Relations Education. - Dissertations (2009): Paper 186. http://epublications.marquette.edu/dissertations_mu/186/.

[36] Kotler, P. (2003): Marketing Management. 11th International Edition. - Prentice Hall, Upper Saddle River, NJ.

[37] Kotler, P., Kartajaya, H., Setiawan, I. (2010): Marketing 3.0: From products to customers to the human spirit. Wiley InterScience (Online service). - Wiley, Hoboken, NJ.

[38] Laroche, M., Bergeron, J., Barbaro-Forleo, G. (2001): Targeting consumers who are willing to pay more for environmentally-friendly products. - Journal of Consumer Marketing 18(6): 503-520.

[39] Lapinski, M. K., Rimal, R. N. (2005): An explication of social norms. - Communication Theory 15: 127-147.

[40] Lapple, D., Kelley, H. (2010): Understanding farmers' uptake of organic farming. An application of the theory of planned behavior. - The 84th Annual Conference of the Agricultural Economics Society Edinburgh, 29th to 31st March 2010.

[41] Lee, K. (2008): Opportunities for green marketing: young consumers. - Marketing Intelligence \& Planning 26(6): 573-586. http://dx.doi.org/10.1108/02634500810902839.

[42] Lin, W. B., Wang, M. K., Hwang, K. P. (2010): The combined model of influencing online consumer behavior. - Expert Systems with Applications 37: 3236-3247.

[43] Liu, S., Kasturiratne, D., Moizer, J. (2012): A hub-and-spoke model for multidimensional integration of green marketing and sustainable supply chain management. Industrial Marketing Management 41: 581-588. DOI: 10.1016/j.indemarman.2012.04.005.

[44] Luchs, M. G., Naylor, R. W., Irwin, J. R., Raghunathan, R. (2010): The sustainability liability: potential negative effects of ethicality on product preference. - Journal of Marketing 74: 18-31. DOI: 10.1509/jmkg.74.5.18.

[45] Madden, T. J., Ellen, P. S., Ajzen, I. (1992): A comparison of the theory of planned behavior and the theory of reasoned action. - Personality and Social Psychology Bulletin 18(3): 3-9.

[46] Maichum, K., Parichatnon, S., Peng, K. C. (2016): Application of the extended theory of planned behavior model to investigate purchase intention of green products among Thai consumers. - Sustainability 8: 1077. DOI: 10.3390/su8101077.

[47] Malhotra, N. K., Lee, O. F., Uslay, C. (2012): Mind the gap: The mediating role of mindful marketing between market and quality orientations, their interaction, and 
consequences. - International Journal of Quality \& Reliability Management 29(6): 607626. DOI: $10.1108 / 02656711211245629$.

[48] Mei, O. J., Ling, K. C., Piew, T. H. (2012): The antecedents of green purchase intention among Malaysian consumers. - Asian Social Science 8(13): 248-264. DOI: 10.5539/ass.v8n13p248.

[49] McCarthy, M., O'Reilly, S., O'Sullivan, A., Guerin, P. (2007): An investigation into the determinants of commitment to organic farming in Ireland. - Journal of Farm Management 13(2): 135-152.

[50] Mintel (2010): Green Living_USA. - Mintel, London.

[51] Montaño, D. E., Kasprzyk, D. (2008): Theory of Reasoned Action, Theory of Planned Behavior, and the Integrated Behavioral Model. - In: Glanz, K., Rimer, B. K., Viswanath, K. (eds.) Health Behavior and Health Education: Theory, Research, and Practice. JosseyBass, San Francisco, CA, pp. 67-96.

[52] Ottman, J. A. (2011): The New Rules of Green Marketing: Strategies Tools, and Inspiration for Sustainable Branding. - Greenleaf Publishing, Sheffield, UK.

[53] Peattie, K. (2001): Towards sustainability: the third age of green marketing. - Marketing Review 2(2): 129.

[54] Peattie, K., Crane, A. (2005): Green marketing: legend, myth, farce or prophesy? - An International Journal 8(4): 357-370.

[55] Polonsky, M. J. (1994): An introduction to green marketing. - Electronic Green Journal 1(2). https://escholarship.org/uc/item/49n325b7.

[56] Polonsky, M. J. (2007): An introduction to green marketing. - Electronic Green Journal 1(2): 1-10.

[57] Polonsky, M. J., Rosenberger, P. J. (2001): Reevaluating green marketing: a strategic approach. - Business Horizons 44(5): 21-30.

[58] Pride, W. M., Ferrell, O. C. (1995): Marketing: Concepts and Strategies. - Houghton Mifflin, Boston.

[59] Punitha, S., Rahman, A. A. (2011): Antecedents of green purchasing behavior among Malaysian consumers. - International Business Management 5(3): 129-139.

[60] Rex, E., Baumann, H. (2007): Beyond Ecolab Les: what green marketing can learn from conventional marketing. - Journal of Cleaner Production 15: 567-576.

[61] Rivera-Camino, J. (2007): Re-evaluating green marketing strategy: A stakeholder perspective. - European Journal of Marketing 41(11): 1328-1358.

[62] Rogers, E. M. (2003): Diffusion of Innovations (5th ed.). - Free Press, New York.

[63] Sabori, SH. (2009): Green Marketing in Iran: Potentials and Challenges. The First Green Marketing Conference in Iran. - http://www.mgtsolution.com/olib/473594249.aspx.

[64] Shahlaee Bagheri, J. (2014): Green marketing and its impacts on consumer behavior in sports shops. - Annals of Applied Sport Science 2(2): 75-82.

[65] Shenoy Devananda, N. A. (2003): Organic Farming Role of NGOs. - Spice India, Cochin, Kerala (India).

[66] Smith, S., Paladino, A. (2010): Eating clean and green? Investigating consumer motivations towards the purchase of organic food. - Australasian Marketing Journal 18(2): 93-104.a.

[67] Soonthensmai, V. (2001): Predicting Intention and Behavior to Purchase Environmentally Sound or Green Products among Thai Consumers: An Application of the Theory of Reasoned Action. - The Wayne Huizenga Graduate School of Business and Entrepreneurship, Nova Southeastern University, DBA.

[68] Soza, F. (2009): Nota Fiscal Paulista: Proposition of a Theoretical Model in Social Marketing. - http://www.procurandorespostas.com/artigos/notafiscalpaulista/.

[69] Suri, M. R. (2014): Non-antibiotic hen. - Javan Online News. http://javanonline.ir/fa/print/688456.

[70] Tanner, C., Kast, S. W. (2003): Promoting sustainable consumption: Determinants of green purchases by Swiss consumers. - Psychology \& Marketing 22(10): 883-902. 
[71] Tarkiainen, A., Sundqvist, S. (2005): Subjective norms, attitudes and intentions of Finnish consumers in buying organic food. - British Food Journal 107(11): 808-822.

[72] Taylor, J. W. (1974): The role of risk in consumer behavior. - The Journal of Marketing 38(2): 54-60.

[73] Taylor, S., Todd, P. (1995): Understanding information technology usage: A test of competing models. - Information Systems Research 6(2): 144-176.

[74] Teisl, M. F., Roe, B., Hicks, R. L. (2002): Can eco-labels tune a market? Evidence from dolphin-safe labeling. - Journal of Environmental Economics and Management 43(3): 339-359.

[75] Wauters, E., Mathijs, E. (2010): A Behavioral Model for the Adoption of Soil Conservation Practices. - Institute for Agricultural and Fisheries Research, Social Sciences Unit, Merelbeke, Belgium. 